\title{
Monitoring candidate gene expression variations before, during and after a first major depressive episode in a 51-year-old man
}

\author{
Raoul Belzeaux ${ }^{1,2,3}$, Jean-Michel Azorin ${ }^{2,3}$ and El Chérif Ibrahim ${ }^{1,3^{*}}$
}

\begin{abstract}
Background: Although psychiatric disorders are frequently characterized by clinical heterogeneity, high recurrence, and unpredictable prognosis, studies of mRNA expression variations in blood cells from psychiatric patients constitute a promising avenue to establish clinical biomarkers. We report here, to our knowledge, the first genetic monitoring of a major depressive episode (MDE).

Case presentation: The subject is a 51-year-old male, who was healthy at baseline and whose blood mRNA was monitored over 67 weeks for expression variations of 9 candidate genes. At week 20 the subject experienced a mild to moderate unexpected MDE, and oral antidepressant treatment was initiated at week 29. At week 36, the patient recovered from his MDE. After 6 months, antidepressant treatment was discontinued and the subject remained free of depressive symptoms. Genetic monitoring revealed that mRNA expression of SLC6A4/5HTT increased with the emergence of a depressive state, which later returned to basal levels after antidepressant treatment and during MDE recovery. PDLIM5, S100A10 and TNF mRNA showed also an interesting pattern of expression with regards to MDE evolution.
\end{abstract}

Conclusion: This case demonstrated the applicability of peripheral mRNA expression as a way to monitor the natural history of MDE.

Keywords: mRNA, Biomarker, 5HTT, TNF, Antidepressant, Major depression

\section{Background}

In psychiatry, biomarker identification remains at its infancy despite advances in pharmacogenomics [1,2], proteomics, as well as translational sciences [3,4]. In recent years, several investigators have reported variations in mRNA levels between patients and control subjects based on peripheral and accessible tissues and also between preand post-treatment conditions in major depressive disorder (MDD) and bipolar disorder (BD) [5-11].

Development of RNA transcripts as biomarkers was facilitated by developments in reverse transcription in combination with quantitative real-time PCR (RT-qPCR), with high sensitivity, specificity, reliability, and at a very

\footnotetext{
* Correspondence: el-cherif.ibrahim@univ-amu.fr

'Aix Marseille Université, CNRS, CRN2M UMR 7286, 51 Bd Pierre Dramard,

13344 cedex 15 Marseille, France

${ }^{3}$ FondaMental, Fondation de Recherche et de Soins en Santé Mentale,

Créteil, France

Full list of author information is available at the end of the article
}

affordable costs [12]. Using these methods, we previously tested mRNA expression variations in blood samples from individuals suffering from severe major depressive episode (MDE), with the aim of validating gene candidates proposed by others as biomarkers in major depression [6].

So far, very few studies have validated the potential significance of such biomarkers $[5,8,11,13]$, and longitudinal studies covering a complete depressive episode from symptoms appearance to full remission are still lacking due to difficulty in conducting prospective studies with subjects that have not yet developed depression. Indeed, little is known about natural mRNA variations occurring over more than 6 months, and which mRNAs may correlate to observable clinical features before, during, and after a MDE. Therefore, both long-term longitudinal studies and individual case studies are needed to better understand gene expression variations.

Here, we describe the variation of mRNA expression levels of selected candidate genes associated with mood 
disorders in a single subject, who was recruited by chance, before, during and after a first MDE. Venous blood was collected from the fasting subject at weeks 0, 2, 8, 29, 41, 43, 50, and 67 in EDTA tubes. Peripheral mononuclear blood cells (PMBCs) were isolated from the blood by Ficoll density centrifugation. Total RNAs were extracted from the PBMCs with the mirVana kit (Ambion) according to the manufacturer's protocol. The purity and integrity of the RNA was determined by optical density measurements and by the Agilent 2100 Bioanalyzer (Agilent Technologies).

We focused our peripheral gene expression analysis on previously identified putative genes involved in the pathophysiology of major depression and its treatments $[6,11,13]$. We selected $S L C 6 A 4 / 5 H T T$, a well known serotonin transporter gene associated with depression vulnerability and a target of most antidepressant treatments [14,15], S100A10, another potential marker of

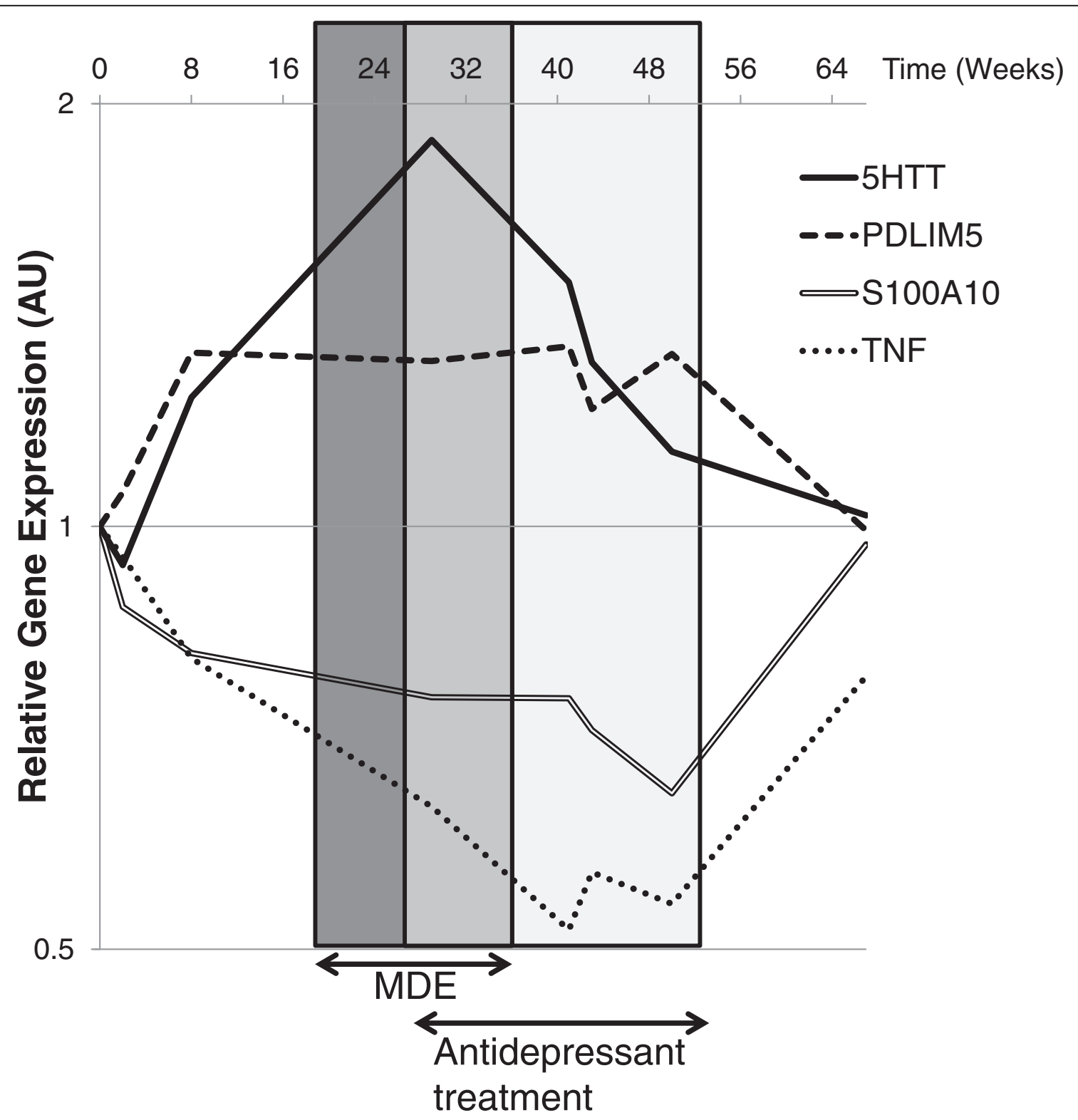

Figure 1 RT-qPCR analysis of SLC6A4/5HTT, PDLIM5, S100A10 and TNF mRNA expression in PBMCs collected at weeks 0, 2, 8, 29, 41, 43, 50, and 67. Patient received antidepressant treatment (Agomelatine, $25 \mathrm{mg} /$ day) between week 29 and week 54 . The reference genes used for normalization were: (i) RPL38 and RPLPO to quantify S100A10 level of expression, (ii) ABL1 and MAPK1 for PDLIM5, (iii) SYNJ2 and ABL1 for IL8 and TNF, (iv) SYNJ2, SYP, and NGFR for CCL2, IL6, IL10 and SLC6A4/5HTT. The calibrator sample was sample at week 0. All qPCR experiments were conducted in duplicate and the mean Ct value was used for FC calculation. 
antidepressant effect encoding p11 [16-18], PDLIM5, encoding a protein associated with mood disorders $[19,20]$, and several cytokines/chemokines playing important roles in regulating immune-inflammatory processes (CCL2, IL1B, IL6, IL8, IL10 and TNF) [21].

Candidate gene expressions were conducted as previously described [6]. The relative fold change expression (FC) was calculated using the $2^{-\Delta \Delta \mathrm{Ct}}$ formula with the DataAssist software (Applied Biosystems, v3.0).

\section{Case presentation}

A 51 year-old male was enrolled as a healthy control in a previously published prospective study of gene expression [6]. Based on the French version of standardized interview validated for healthy control subjects (SCIDNP) [22], the patient did not have a history of psychiatric disorder or other notable medical conditions prior to and at the time of his inclusion. Nevertheless, at week 20 after inclusion, he experienced a mild to moderate MDE, which was diagnosed based on the occurrence of depressive mood, anhedonia, psychomotor retardation, asthenia, and thoughts of death. He consented to stay in the study despite this medical event and was switched to the MDE group of the same study protocol. Following the MDE, the subject retrospectively reported soft depressive signs, such as isolated feelings of worthlessness and hopelessness, that first appeared at week 14 of the study. He initiated oral antidepressant treatment at week 29 (Agomelatine, $25 \mathrm{mg} /$ day) and recovered from his MDE at week 36. After 6 months, the treatment was stopped and the subject remained free of depressive symptoms for the last weeks of our follow-up.

Among the genes investigated, the 4 genes (SLC6A4/ 5HTT, PDLIM5, S100A10 and TNF) that showed the most interesting variations are shown on Figure 1 . The expression of SLC6A4/5HTT exhibited a biphasic variation consisting of an increase during the symptomatic phase and a return to normal level after antidepressant treatment. Interestingly, we found a similar pattern of gene expression variations for PDLIM5. Of note, SLC6A4/5HTT expression was inversely correlated to IL10 expression (Spearman's coefficient correlation $\rho=-0.71, \mathrm{p}=0.047$, false discovery rate $(\mathrm{FDR})=0.161)$. Conversely, S100A10 demonstrated variations in the opposite direction compared to SLC6A4/ $5 H T T$, and was also strongly correlated to TNF variation $(\rho=0.86, \mathrm{p}=0.007, \mathrm{FDR}=0.067), I L 1 B(\rho=0.81, \mathrm{p}=$ $0.015, \mathrm{FDR}=0.067)$ and $C C L 2(\rho=0.83, \mathrm{p}=0.010, \mathrm{FDR}=$ $0.067)$, Finally, $T N F$, which demonstrated an opposite pattern of expression compared to PDLIM5, was strongly correlated to important mediators of inflammation such as $I L 1 B(\rho=0.93, p=0.001$, FDR $=0.036), I L 8(\rho=$ $0.81, \mathrm{p}=0.015, \mathrm{FDR}=0.067)$, and CCL2 $(\rho=0.81, \mathrm{p}=$ $0.015, \mathrm{FDR}=0.067)$.

\section{Conclusions}

We present here, to the best of our knowledge, the first case report of gene expression variations before, during and after an MDE over a large period of 67 weeks. Of note, a previous case report had described a patient suffering from $\mathrm{BD}$ with rapid cycling, and evaluated over a period of time the clinical symptoms and gene expression with genome-wide microarray hybridization and RT-qPCR using cells collected from peripheral blood [23]. In that study, genes involved in prostaglandin metabolism and immune system regulation were expressed in an episode-specific manner (i.e., depressed versus manic episodes).

This case report provides two new insights. First, we observed that gene expression variation of selected genes could precede clinical observable manifestations. This observation is of high interest in the context of biomarker identification, particularly for target biomarkers that could be used to track evolution of symptomatology and may be predictive of either relapse or recurrence [13]. The return of SLC6A4/5HTT mRNA expression to baseline level after antidepressant treatment could be used as a biological definition and general method to predict remission. Secondly, our results suggest that several biological pathways may play important roles during MDE. This case report indicates that SLC6A4/5HTT mRNA regulation could be implicated in MDE independently of treatment effect. Moreover, several genes implicated in immune response were also dysregulated, confirming the immune dysregulation in MDD [24,25].

Our correlation analysis on repeat measurements of gene expression allowed us to propose a potential link between the serotonin pathway and inflammation dysregulation [26,27], as well as a link between S100A10 and TNF, which has been suggested in previous studies [28].

Despite these new insights, the results presented here have some limitations. First of all, it is difficult to draw general conclusions based on an isolated case of MDE patient. Replications are warranted but finding similar cases would require a very large prospective cohort within healthy subjects or individuals at risk for an MDE. Moreover, the inherent physiological or stochastic variations in gene expression could contribute to the observed variations and little is known about variation of gene expression of candidate genes such as SLC6A4/5HTT [29]. Finally, we favored a candidate gene approach and restricted our analysis to a few genes of interest. Of note, other candidate biomarker genes such as FKBP5 could also be informative in such a case and deserve further investigations [30,31].

In conclusion, gene expressions in blood tissue could pave the way to biomarker description in mood disorder as described here. Even if cohort studies are the gold standard to develop such aim, intra-individual variation 
and single case report could uncover some new insights in the field of personalized medicine.

\section{Consent}

Written informed consent was obtained from the patient for publication of this Case report. A copy of the written consent is available for review by the Editor of this journal.

\section{Abbreviations}

MDE: Major depressive episode; MDD: Major depressive disorder; BD: Bipolar disorder; PBMC: Peripheral blood mononuclear Cell; RT-qPCR: Reverse transcription in combination with quantitative real-time PCR; FC: Fold change; FDR: False discovery rate.

\section{Competing interests}

The authors declare that they have no competing interests.

\section{Authors' contributions}

$\mathrm{RB}$ and $\mathrm{El}$ conceived the study. RB carried out the clinical evaluation. El performed the genetic experiments. RB and El analysed the results. All authors drafted, read, and approved the final manuscript.

\section{Acknowledgments}

This study was supported by grants from Assistance Publique-Hôpitaux de Marseille (Ref. No. AORC 2009-15) and a national hospital clinical research program (PHRC, No. 2010-19). We are grateful to the VEGA nurse team, Christine Formisano-Tréziny, Jean Gabert, and Anderson Loundou for their technical support. We also thank Jeanne Hsu and Frank Bellivier for their critical reading of the manuscript.

\section{Author details}

${ }^{1}$ Aix Marseille Université, CNRS, CRN2M UMR 7286, 51 Bd Pierre Dramard, 13344 cedex 15 Marseille, France. ${ }^{2}$ APHM, Hôpital Sainte Marguerite, Pôle de Psychiatrie Universitaire Solaris, 13274 cedex 9 Marseille, France.

${ }^{3}$ FondaMental, Fondation de Recherche et de Soins en Santé Mentale, Créteil, France.

Received: 15 January 2014 Accepted: 10 March 2014

Published: 12 March 2014

\section{References}

1. de Leon J: Pharmacogenomics: the promise of personalized medicine for CNS disorders. Neuropsychopharmacology 2009, 34(1):159-172.

2. Porcelli S, Drago A, Fabbri C, Gibiino S, Calati R, Serretti A: Pharmacogenetics of antidepressant response. J Psychiatry Neurosci 2011, 36(2):87-113.

3. Pajer K, Andrus BM, Gardner W, Lourie A, Strange B, Campo J, Bridge J, Blizinsky K, Dennis K, Vedell P, Churchill GA, Redei EE: Discovery of blood transcriptomics markers for depression in animal models and pilot validation in subjects with early-onset major depression. Trans/ Psychiatry 2012, 2:e101.

4. Niculescu AB, Le-Niculescu H: Convergent functional genomics: what we have learned and can learn about genes, pathways, and mechanisms. Neuropsychopharmacology 2010, 35(1):355-356

5. Mamdani F, Berlim MT, Beaulieu MM, Turecki G: Pharmacogenomic predictors of citalopram treatment outcome in major depressive disorder. World J Biol Psychiatry 2014, 15(2):135-144.

6. Belzeaux R, Formisano-Treziny C, Loundou A, Boyer L, Gabert J, Samuelian JC, Feron F, Naudin J, Ibrahim EC: Clinical variations modulate patterns of gene expression and define blood biomarkers in major depression. J Psychiatr Res 2010, 44(16):1205-1213.

7. Spijker S, Van Zanten JS, De Jong S, Penninx BW, van Dyck R, Zitman FG, Smit JH, Ylstra B, Smit AB, Hoogendijk WJ: Stimulated gene expression profiles as a blood marker of major depressive disorder. Biol Psychiatry 2010, 68(2):179-186

8. Mamdani F, Berlim MT, Beaulieu M-M, Labbe A, Merette C, Turecki G: Gene expression biomarkers of response to citalopram treatment in major depressive disorder. Transl Psychiatry 2011, 1:e13.
9. Yi Z, Li Z, Yu S, Yuan C, Hong W, Wang Z, Cui J, Shi T, Fang Y: Blood-based gene expression profiles models for classification of subsyndromal symptomatic depression and major depressive disorder. PLoS One 2012, 7(2):e31283.

10. Munkholm K, Vinberg M, Berk M, Kessing LV: State-related alterations of gene expression in bipolar disorder: a systematic review. Bipolar Disord 2012, 14(7):684-696.

11. Belzeaux R, Bergon A, Jeanjean V, Loriod B, Formisano-Treziny C, Verrier L, Loundou A, Baumstarck-Barrau K, Boyer L, Gall V, Gabert J, Nguyen C, Azorin $J M$, Naudin J, Ibrahim EC: Responder and nonresponder patients exhibit different peripheral transcriptional signatures during major depressive episode. Transl Psychiatry 2012, 2:e185.

12. Ruijter JM, Pfaffl MW, Zhao S, Spiess AN, Boggy G, Blom J, Rutledge RG, Sisti D, Lievens A, De Preter K, Derveaux S, Hellemans J, Vandesompele J: Evaluation of qPCR curve analysis methods for reliable biomarker discovery: bias, resolution, precision, and implications. Methods 2013, 59(1):32-46.

13. Cattaneo A, Gennarelli M, Uher R, Breen G, Farmer A, Aitchison KJ, Craig IW, Anacker C, Zunsztain PA, McGuffin P, Pariante CM: Candidate genes expression profile associated with antidepressants response in the GENDEP study: differentiating between baseline 'predictors' and longitudinal 'targets'. Neuropsychopharmacology 2013, 38(3):377-385.

14. Tsao CW, Lin YS, Chen CC, Bai CH, Wu SR: Cytokines and serotonin transporter in patients with major depression. Prog Neuropsychopharmacol Biol Psychiatry 2006, 30(5):899-905.

15. Iga J, Ueno S, Yamauchi K, Motoki I, Tayoshi S, Ohta K, Song H, Morita K, Rokutan K, Ohmori T: Serotonin transporter mRNA expression in peripheral leukocytes of patients with major depression before and after treatment with paroxetine. Neurosci Lett 2005, 389(1):12-16.

16. Alexander B, Warner-Schmidt J, Eriksson T, Tamminga C, Arango-Lievano M, Ghose S, Vernov M, Stavarache M, Musatov S, Flajolet M, Svenningsson P, Greengard P, Kaplitt MG: Reversal of depressed behaviors in mice by $\mathrm{p} 11$ gene therapy in the nucleus accumbens. Sci Trans/ Med 2010, 2(54):54ra76.

17. Zhang L, Su TP, Choi K, Maree W, Li CT, Chung MY, Chen YS, Bai YM, Chou YH, Barker JL, Barrett JE, Li XX, Li H, Benedek DM, Ursano R: P11 (S100A10) as a potential biomarker of psychiatric patients at risk of suicide. J Psychiatr Res 2011, 45(4):435-441.

18. Melas PA, Rogdaki M, Lennartsson A, Bjork K, Qi H, Witasp A, Werme M, Wegener G, Mathe AA, Svenningsson P, Lavebratt C: Antidepressant treatment is associated with epigenetic alterations in the promoter of P11 in a genetic model of depression. Int J Neuropsychopharmacol 2012, 15(5):669-679.

19. Wong ML, Dong C, Andreev V, Arcos-Burgos M, Licinio J: Prediction of susceptibility to major depression by a model of interactions of multiple functional genetic variants and environmental factors. Mol Psychiatry 2012, 17(6):624-633.

20. Iga J, Ueno S, Yamauchi K, Numata S, Motoki I, Tayoshi S, Kinouchi S, Ohta K, Song H, Morita K, Rokutan K, Tanabe H, Sano A, Ohmori T: Gene expression and association analysis of LIM (PDLIM5) in major depression. Neurosci Lett 2006, 400(3):203-207.

21. Dowlati Y, Herrmann N, Swardfager W, Liu H, Sham L, Reim EK, Lanctot KL: A metaanalysis of cytokines in major depression. Biol Psychiatry 2010, 67(5):446-457.

22. Spitzer RL, Williams JBW, Gibbon M: Structured clinical interview for DSM-III-R, patient edition/non-patient edition, (SCID-P/SCID-NP). Washington, D.C.: American Psychiatric Press; 1990.

23. Begemann M, Sargin D, Rossner MJ, Bartels C, Theis F, Wichert SP, Stender N, Fischer B, Sperling S, Stawicki S, Wiedl A, Falkai P, Nave KA, Ehrenreich H: Episode-specific differential gene expression of peripheral blood mononuclear cells in rapid cycling supports novel treatment approaches. Mol Med 2008, 14(9-10):546-552.

24. Gibney SM, Drexhage HA: Evidence for a dysregulated immune system in the etiology of psychiatric disorders. J Neuroimmune Pharmacol 2013, 8(4):900-920.

25. Dantzer R, O'Connor JC, Freund GG, Johnson RW, Kelley KW: From inflammation to sickness and depression: when the immune system subjugates the brain. Nat Rev Neurosci 2008, 9(1):46-56.

26. Dantzer R, O'Connor JC, Lawson MA, Kelley KW: Inflammation-associated depression: from serotonin to kynurenine. Psychoneuroendocrinology 2011, 36(3):426-436.

27. Miller AH, Haroon E, Raison CL, Felger JC: Cytokine targets in the brain: impact on neurotransmitters and neurocircuits. Depress Anxiety 2013 30(4):297-306. 
28. Warner-Schmidt JL, Vanover KE, Chen EY, Marshall JJ, Greengard P: Antidepressant effects of selective serotonin reuptake inhibitors (SSRIs) are attenuated by antiinflammatory drugs in mice and humans. Proc Natl Acad Sci U S A 2011, 108(22):9262-9267.

29. Sibille E, Lewis DA: SERT-ainly involved in depression, but when? Am J Psychiatry 2006, 163(1):8-11.

30. Menke A, Arloth J, Putz B, Weber P, Klengel T, Mehta D, Gonik M, Rex-Haffner M, Rubel J, Uhr M, Lucae S, Deussing JM, Müller-Myhsok B, Holsboer F, Binder EB: Dexamethasone stimulated gene expression in peripheral blood is a sensitive marker for glucocorticoid receptor resistance in depressed patients. Neuropsychopharmacology 2012, 37(6):1455-1464.

31. Menke A, Klengel T, Rubel J, Bruckl T, Pfister H, Lucae S, Uhr M, Holsboer F, Binder EB: Genetic variation in FKBP5 associated with the extent of stress hormone dysregulation in major depression. Genes Brain Behav 2013, 12(3):289-296.

doi:10.1186/1471-244X-14-73

Cite this article as: Belzeaux et al:: Monitoring candidate gene expression variations before, during and after a first major depressive episode in a 51-year-old man. BMC Psychiatry 2014 14:73.

\section{Submit your next manuscript to BioMed Central and take full advantage of:}

- Convenient online submission

- Thorough peer review

- No space constraints or color figure charges

- Immediate publication on acceptance

- Inclusion in PubMed, CAS, Scopus and Google Scholar

- Research which is freely available for redistribution 